\title{
Discovery of a new series of imidazo[1,2-a]pyridine compounds as selective c-Met inhibitors
}

\author{
Tong-chao LIU ${ }^{1,2}$, Xia PENG ${ }^{3}$, Yu-chi MA², Yin-chun $\mathrm{JI}^{3}$, Dan-qi CHEN², Ming-yue ZHENG ${ }^{2}$, Dong-mei ZHAO ${ }^{1, *}$, \\ Mao-sheng $\mathrm{CHENG}^{1}$, Mei-yu GENG ${ }^{3}$, Jing-kang $\mathrm{SHEN}^{2}$, Jing $\mathrm{Al}^{3, *}$, Bing XIONG${ }^{2, *}$
}

${ }^{1}$ Key Laboratory of Structure-Based Drug Design \& Discovery of Ministry of Education, Shenyang Pharmaceutical University, Shenyang 110016, China; ' ${ }^{2}$ Department of Medicinal Chemistry, State Key Laboratory of Drug Research, Shanghai Institute of Materia Medica, Chinese Academy of Sciences, Shanghai 201203, China; ${ }^{3}$ Division of Anti-tumor Pharmacology, State Key Laboratory of Drug Research, Shanghai Institute of Materia Medica, Chinese Academy of Sciences, Shanghai 201203, China

\begin{abstract}
Aim: Aberrant c-Met activation plays a critical role in cancer formation, progression and dissemination, as well as in development of resistance to anticancer drugs. Therefore, c-Met has emerged as an attractive target for cancer therapy. The aim of this study was to develop new c-Met inhibitors and elaborate the structure-activity relationships of identified inhibitors.

Methods: Based on the predicted binding modes of Compounds 5 and 14 in docking studies, a new series of c-Met inhibitor-harboring 3-((1H-pyrrolo[3,2-c]pyridin-1-yl)sulfonyl)imidazo[1,2-a]pyridine scaffolds was discovered. Potent inhibitors were identified through extensive optimizations combined with enzymatic and cellular assays. A promising compound was further investigated in regard to its selectivity, its effects on c-Met signaling, cell proliferation and cell scattering in vitro.

Results: The most potent Compound 31 inhibited c-Met kinase activity with an $\mathrm{IC}_{50}$ value of $12.8 \mathrm{nmol} / \mathrm{L}$, which was $>78-$ fold higher than those of a panel of 16 different tyrosine kinases. Compound 31 (8, 40, $200 \mathrm{nmol} / \mathrm{L})$ dose-dependently inhibited the phosphorylation of c-Met and its key downstream Akt and ERK signaling cascades in c-Met aberrant human EBC-1 cancer cells. In 12 human cancer cell lines harboring different background levels of c-Met expression/activation, Compound 31 potently inhibited c-Metdriven cell proliferation. Furthermore, Compound $\mathbf{3 1}$ dose-dependently impaired c-Met-mediated cell scattering of MDCK cells. Conclusion: This series of c-Met inhibitors is a promising lead for development of novel anticancer drugs.
\end{abstract}

Keywords: c-Met inhibitors; hepatocyte growth factor receptor; imidazo[1,2-a]pyridine; anticancer agents; drug discovery

Acta Pharmacologica Sinica (2016) 37: 698-707; doi: 10.1038/aps.2016.11; published online 4 Apr 2016

\section{Introduction}

c-Met, also known as hepatocyte growth factor receptor (HGFR), was discovered in 1984 as an oncogenic fusion protein $^{[1]}$. Since then, extensive investigations on the structure and functions of c-Met have shown that it belongs to a unique subfamily of receptor tyrosine kinases (RTKs) ${ }^{[2]}$ and forms a heterodimer by connecting a short extracellular a chain and a membrane spanning $\beta$ chain through a disulfide bond. After binding to its natural ligand, hepatocyte growth factor (HGF), c-Met initiates its kinase phosphorylation activity and triggers a series of downstream signaling pathways, including PI3KAKT-mTOR and Ras-MEK-ERK ${ }^{[3-7]}$. Abnormal activation of

\footnotetext{
* To whom correspondence should be addressed.

E-mail bxiong@simm.ac.cn (Bing XIONG); jai@simm.ac.cn (Jing Al)

Received 2015-11-10 Accepted 2016-01-05
}

c-Met has been linked to many types of cancers that occur as a consequence of gene amplification or rearrangement, transcriptional regulation, as well as autocrine or paracrine ligand stimulation $^{[8]}$. Importantly, both c-Met and HGF elevation have been associated with poor clinical outcomes ${ }^{[9]}$. Moreover, aberrant c-Met activation plays a critical role in cancer formation, progression, and dissemination and in the development of resistance against approved therapies. Therefore, c-Met has emerged as an attractive target for cancer therapy ${ }^{[10-16]}$.

Currently, the most promising approach for disrupting c-Met signaling is to use small molecular inhibitors to target the intracellular kinase domain. Through the analysis of binding modes, small molecule inhibitors of c-Met can be roughly classified into three types. Type I c-Met inhibitors bind to ATP binding pockets in a " $U$ " shape, which usually interacts with residue Met1211 at the hinge part to anchor the inhibitor and forms a typical $\Pi-\Pi$ stacking interaction with residue 
<smiles>CC(Oc1cc(-c2cnn(C3CCNCC3)c2)cnc1N)c1c(Cl)ccc(F)c1Cl</smiles>

Crizotinib (1)

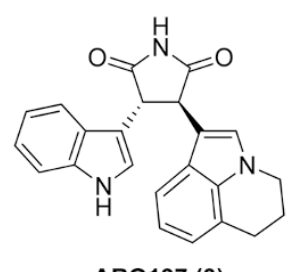

ARQ197 (3)

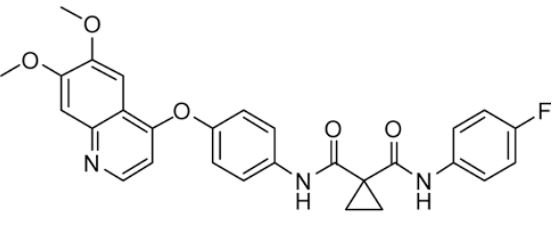

Cabozantinib (2)

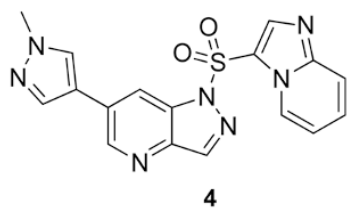

Figure 1. Representative c-Met inhibitors.

Tyr1230 ${ }^{[17]}$. As implied by the unique U-shaped binding mode, type I inhibitors (such as crizotinib 1) all show good selectivity for c-Met and are expected to cause fewer side effects in cancer treatment ${ }^{[18]}$. Type II c-Met inhibitors (such as cabozantinib 2) are usually multi-kinase inhibitors and adopt extended conformations, starting from the solvent-accessible part to hinge and further stretching to the deep hydrophobic Ile1145 subpocket near the C-helix region ${ }^{[19]}$. Except for the above-mentioned well-classified inhibitors, there are other atypical c-Met inhibitors, such as ARQ197 (3), that are all classified as type III c-Met inhibitors ${ }^{[20]}$.

Previously, we elaborated on the synthesis of a series of pyrazol[4,3-b]pyridine compounds and their potent and selective activities as c-Met inhibitors (lead compound 4$)^{[21]}$. During the optimization process, we synthesized an interesting compound (5) containing two possible hinge binders, an imidazole ring and an imidazo[1,2-a]pyridine ring, which could form an essential hydrogen bonding interaction with the backbone of Met1160. Considering its interesting binding mode and good enzymatic activity, we initialized a medicinal chemistry modification with the aim of finding a novel series of c-Met inhibitors for the further development of anti-cancer drugs.

\section{Materials and methods} Chemistry

Scheme 1
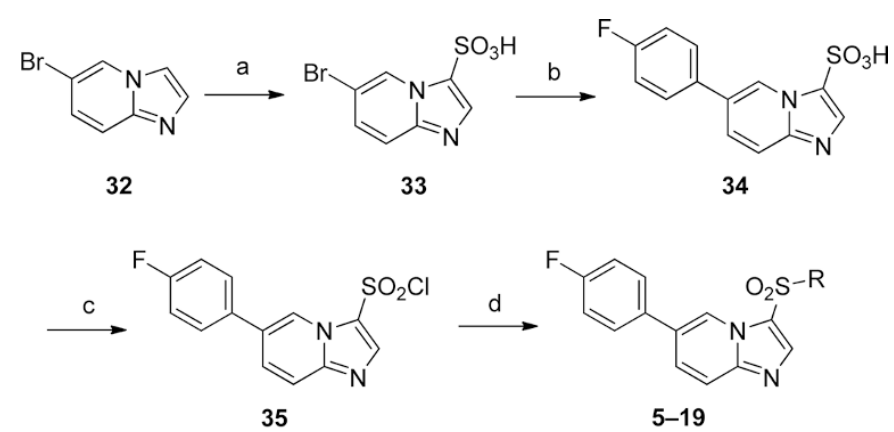

Reagents and conditions: (a) $\mathrm{ClSO}_{3} \mathrm{H}, \mathrm{CHCl}_{3}$, Reflux, $24 \mathrm{~h}$, 98\%; (b) (4-fluorophenyl)boronic acid, $\mathrm{Pd}(\mathrm{dppf}) \mathrm{Cl}_{2}, \mathrm{~K}_{2} \mathrm{CO}_{3}$, $90{ }^{\circ} \mathrm{C}, 3 \mathrm{~h}, 70.9 \%$; (c) phosphorus oxychloride, reflux, $24 \mathrm{~h}$, $51 \%$; (d) NaH, DMF, room temperature, $4 \mathrm{~h}$.

Compounds 5-19 were prepared according to the procedure shown in Scheme 1. Commercially available 32 was sulfonylated to afford 33. Conventional Suzuki coupling of 33 with (4-fluorophenyl)boronic acid afforded compound 34. Treatment of compound 34 with phosphorus oxychloride afforded compound 35. Compounds 5-19 were prepared by subjecting compound 35 to condensation with the appropriate pyrrole derivatives.

\section{Scheme 2}
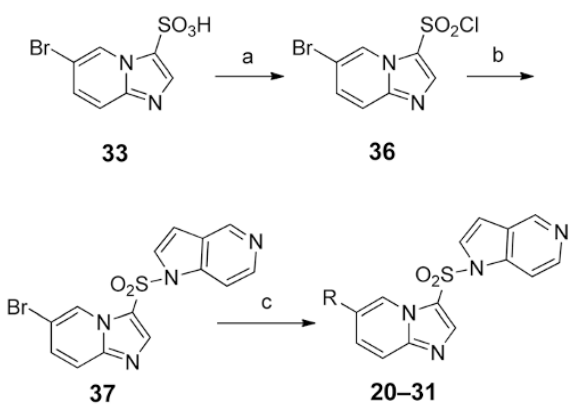

Reagents and conditions: (a) phosphorus oxychloride, reflux, 24 h, 51\%; (b) 1H-pyrrolo[3,2-c]pyridine, NaH, DMF, room temperature, $4 \mathrm{~h}, 60 \%$; (c) R-boronic acid or R-boronic acid pinacol ester, $\mathrm{PdCl}_{2}$ (dppf)- $\mathrm{CH}_{2} \mathrm{Cl}_{2}, \mathrm{~K}_{2} \mathrm{CO}_{3}, 90^{\circ} \mathrm{C}, 30 \mathrm{~min}, 31 \%-$ $81 \%$.

Compounds 20-31 were synthesized according to the procedures outlined in Scheme 2. Compound 33 was treated with phosphorus oxychloride to afford compound 36. Compound 37 was prepared by deprotonating 5-azaindole, which was followed by the addition of compound 36. A variety of aryl groups were introduced at the 6-position of compound 37 via Suzuki coupling reactions to provide compounds 20-31.

${ }^{1} \mathrm{H}$ NMR (400 MHz) spectra were recorded using a Varian Mercury-400 High Performance Digital FT-NMR spectrometer using tetramethylsilane (TMS) as an internal standard. Abbreviations for peak patterns in the NMR spectra are as follows: br=broad, $\mathrm{s}=$ singlet, $\mathrm{d}=$ doublet, and $\mathrm{m}=$ multiplet. Low-resolution mass spectra were obtained with a Finnigan LCQ Deca XP mass spectrometer using a CAPCELL PAK C18 (50 mm×2.0 $\mathrm{mm}, 5 \mathrm{ZM}$ ) or an Agilent ZORBAX Eclipse XDB C18 (50 $\mathrm{mm} \times 2.1 \mathrm{~m}, 5 \mathrm{ZM}$ ) column in positive or negative electrospray mode. The purities of all the compounds were determined by analytical Gilson high-performance liquid chromatography (HPLC) using an YMC ODS3 column ( $50 \mathrm{~mm} \times 4.6 \mathrm{~mm}, 5 \mathrm{ZM})$ using the following conditions: $\mathrm{CH}_{3} \mathrm{CN} / \mathrm{H}_{2} \mathrm{O}$ eluent at 2.5 $\mathrm{mL} / \mathrm{min}$ flow [containing $0.1 \%$ trifluoroacetic acid (TFA)] at $35^{\circ} \mathrm{C}, 8 \mathrm{~min}$, gradient $5 \% \mathrm{CH}_{3} \mathrm{CN}$ to $95 \% \mathrm{CH}_{3} \mathrm{CN}$, monitored by UV absorption at $214 \mathrm{~nm}$ and $254 \mathrm{~nm}$. TLC analyses were carried out using glass precoated silica gel GF254 plates. The 
TLC spots were visualized under UV light. Flash column chromatography was performed using a Teledyne ISCO CombiFlash Rf system. All the solvents and reagents were used as received unless otherwise noted. Anhydrous dimethylformamide was purchased from Acros and was used without further drying. All air- and moisture-sensitive reactions were carried out under an atmosphere of dry argon with heat-dried glassware using standard syringe techniques.

\section{General procedure for the syntheses of 5-19}

6-Bromoimidazo[1,2-a]pyridine-3-sulfonic acid (33). Cholrosulfonic acid $(1.01 \mathrm{~mL}, 15.3 \mathrm{mmol})$ was dissolved in chloroform $(10 \mathrm{~mL})$, and this solution was added dropwise to 6-bromoimidazo[1,2-a]pyridine $(1.00 \mathrm{~g}, 5.1 \mathrm{mmol})$ in chloroform $(15 \mathrm{~mL})$ over $20 \mathrm{~min}$. The reaction mixture was refluxed for $24 \mathrm{~h}$, allowed to cool to room temperature and concentrated to dryness under vacuum. The crude oily product was treated with diethyl ether $(20 \mathrm{~mL})$ and ethanol $(10 \mathrm{~mL})$, which resulted in the collection of a white precipitate. The solid was collected by filtration, washed with EtOH and dried to afford 6-bromoimidazo[1,2-a]pyridine-3-sulfonic acid (33) (1.38 g, $98 \%$ yield). MS $m / z$ (ESI) found $275,277(\mathrm{M}-\mathrm{H})^{+},{ }^{1} \mathrm{H}$ NMR $(400$ MHz, DMSO- $\left.d^{6}\right) \delta 8.93(\mathrm{dd}, \mathrm{J}=1.8,0.8 \mathrm{~Hz}, 1 \mathrm{H}), 8.30(\mathrm{~s}, 1 \mathrm{H})$, $8.13(\mathrm{dd}, \mathrm{J}=9.5,1.8 \mathrm{~Hz}, 1 \mathrm{H}), 7.95(\mathrm{dd}, \mathrm{J}=9.5,0.8 \mathrm{~Hz}, 1 \mathrm{H})$; the $\mathrm{OH}$ on sulfonic acid is missing.

6-(4-fluorophenyl)imidazo[1,2-a]pyridine-3-sulfonic acid (34). A solution of $33(4 \mathrm{~g}, 14.4 \mathrm{mmol})$, (4-fluorophenyl) boronic acid (2.4 g, $17.3 \mathrm{mmol}), \mathrm{PdCl}_{2}(\mathrm{dppf})-\mathrm{CH}_{2} \mathrm{Cl}_{2}(590 \mathrm{mg}$, $0.72 \mathrm{mmol})$ and $\mathrm{K}_{2} \mathrm{CO}_{3}(7.97 \mathrm{~g}, 57.8 \mathrm{mmol})$ in 1,4-dioxane:water $(40 \mathrm{~mL}, 2: 1, v / v)$ in a microwave tube was flushed with $\mathrm{N}_{2}$ for $5 \mathrm{~min}$ and then sealed. The tube was placed in the microwave cavity and heated at $90^{\circ} \mathrm{C}$ for $1 \mathrm{~h}$. Then, the reaction mixture was evaporated to dryness. The residue was diluted with water $(60 \mathrm{~mL})$, filtered and washed with water $(20 \mathrm{~mL})$. The $\mathrm{pH}$ of the filtrate was adjusted to $1-2$ with $1 \mathrm{~mol} / \mathrm{L}$ aqueous $\mathrm{HCl}$, and white precipitate appeared. The precipitate was filtered and dried under vacuum to give $34(2.98 \mathrm{~g}, 70.9 \%$ yield). MS $m / z$ (ESI) found $291(\mathrm{M}-\mathrm{H})^{+}, 293(\mathrm{M}+\mathrm{H})^{+} ;{ }^{1} \mathrm{H}$ NMR $\left(400 \mathrm{MHz}, \mathrm{DMSO}-d^{6}\right) \delta 8.97(\mathrm{~s}, 1 \mathrm{H}), 8.33(\mathrm{~d}, \mathrm{~J}=2.3 \mathrm{~Hz}, 1 \mathrm{H})$, $8.30(\mathrm{~d}, \mathrm{~J}=9.3 \mathrm{~Hz}, 1 \mathrm{H}), 8.05(\mathrm{~d}, \mathrm{~J}=9.4 \mathrm{~Hz}, 1 \mathrm{H}), 8.04(\mathrm{~s}, 0 \mathrm{H}), 7.81$ $-7.67(\mathrm{~m}, 2 \mathrm{H}), 7.44(\mathrm{t}, \mathrm{J}=8.3 \mathrm{~Hz}, 2 \mathrm{H})$; the $\mathrm{OH}$ on sulfonic acid is missing.

6-(4-fluorophenyl)imidazo[1,2-a]pyridine-3-sulfonyl chloride (35). Compound $34(2.98 \mathrm{~g}, 10.2 \mathrm{mmol})$ was treated with phosphorus oxychloride $(60 \mathrm{~mL})$ and refluxed for $24 \mathrm{~h}$. The reaction mixture was cooled to room temperature and treated with DCM $(100 \mathrm{~mL})$, poured over ice-cold water $(100 \mathrm{~mL})$, and then extracted with DCM $(4 \times 50 \mathrm{~mL})$. The organic layers were combined, dried $\left(\mathrm{Na}_{2} \mathrm{SO}_{4}\right)$, filtered, and concentrated to dryness under vacuum to give crude 35 . The crude product was purified by flash chromatography to give purified compound 35 (1.6 g, 51\%). MS m/z (ESI) found $311(\mathrm{M}+\mathrm{H})^{+} ;{ }^{1} \mathrm{H}$ NMR $(400$ MHz, chloroform- $d$ ) $\delta 8.82(\mathrm{~s}, 1 \mathrm{H}), 8.40(\mathrm{~s}, 1 \mathrm{H}), 7.94(\mathrm{~d}, \mathrm{~J}=9.3$ $\mathrm{Hz}, 1 \mathrm{H}), 7.84(\mathrm{~d}, \mathrm{~J}=9.3 \mathrm{~Hz}, 1 \mathrm{H}), 7.60(\mathrm{dd}, \mathrm{J}=8.7,5.2 \mathrm{~Hz}, 2 \mathrm{H})$, 7.30-7.17 (m, 2H).

3-((1H-imidazol-1-yl)sulfonyl)-6-(4-fluorophenyl)imi- dazo[1,2-a]pyridine (5). $\mathrm{NaH}(10.3 \mathrm{mg}, 0.258 \mathrm{mmol})$ was first dissolved in $1 \mathrm{~mL}$ of anhydrous DMF. Imidazole (10.5 $\mathrm{mg}, 0.155 \mathrm{mmol}$ ) dissolved in $1 \mathrm{~mL}$ of anhydrous DMF was slowly added dropwise, and the mixture was stirred for 30 min. Compound 35 ( $40 \mathrm{mg}, 0.129 \mathrm{mmol})$ dissolved in $1 \mathrm{~mL}$ of anhydrous DMF was slowly added dropwise, and the mixture was stirred for $3 \mathrm{~h}$ at room temperature. The reaction solution was poured into $0.1 \mathrm{~mol} / \mathrm{L}$ hydrochloric acid, which was then turned basic using an aqueous sodium bicarbonate solution and extracted with ethyl acetate. The organic layer was collected, and distilled under reduced pressure. The residue was purified by flash chromatography to afford compound 5 (26 mg, 60\%). MS m/z (ESI) found $343(\mathrm{M}+\mathrm{H})^{+} ;{ }^{1} \mathrm{H}$ NMR $(400$ MHz, chloroform- $d$ ) $\delta 8.67(\mathrm{~s}, 1 \mathrm{H}), 8.43(\mathrm{~s}, 1 \mathrm{H}), 8.13(\mathrm{~s}, 1 \mathrm{H})$, $7.88(\mathrm{~d}, \mathrm{~J}=9.0 \mathrm{~Hz}, 1 \mathrm{H}), 7.74(\mathrm{~d}, \mathrm{~J}=9.6 \mathrm{~Hz}, 1 \mathrm{H}), 7.56-7.39(\mathrm{~m}, 2 \mathrm{H})$, $7.36(\mathrm{~s}, 1 \mathrm{H}), 7.27-7.19(\mathrm{~m}, 2 \mathrm{H}), 7.12(\mathrm{~s}, 1 \mathrm{H})$. Retention time 3.02 $\min , 100 \%$ pure.

The details of compounds 6-19 are provided in the Supporting Material.

\section{General procedure for the syntheses of 20-31}

6-Bromoimidazo[1,2-a]pyridine-3-sulfonyl chloride (36). Compound 36 was prepared according to the procedure for 35. $34 \%$ yield; MS $\mathrm{m} / z$ (EI) found $296(\mathrm{M})^{+} ;{ }^{1} \mathrm{H}-\mathrm{NMR}(400 \mathrm{MHz}$, $\left.\mathrm{CDCl}_{3}\right) \delta 8.97(\mathrm{~m}, 1 \mathrm{H}), 8.47(\mathrm{~s}, 1 \mathrm{H}), 7.89(\mathrm{~d}, J=9.6 \mathrm{~Hz}, 1 \mathrm{H}), 7.83$ $(\mathrm{dd}, J=9.6,1.7 \mathrm{~Hz}, 1 \mathrm{H})$.

3-((1H-pyrrolo[3,2-c]pyridin-1-yl)sulfonyl)-6-bromoimidazo[1,2-a]pyridine (37). NaH $(0.88 \mathrm{~g}, 22 \mathrm{mmol})$ was suspended in $10 \mathrm{~mL}$ of anhydrous DMF and cooled to $0^{\circ} \mathrm{C}$ in an ice bath. 1H-pyrrolo[3,2-c]pyridine $(1.3 \mathrm{~g}, 11 \mathrm{mmol})$ dissolved in $10 \mathrm{~mL}$ of anhydrous DMF was slowly added dropwise, and the mixture was stirred for $30 \mathrm{~min}$ at $0^{\circ} \mathrm{C}$. Compound 36 ( $3.9 \mathrm{~g}, 13.2 \mathrm{mmol})$ dissolved in $15 \mathrm{~mL}$ of anhydrous DMF was added in dropwise, and the reaction mixture was stirred for 4 $\mathrm{h}$ at room temperature. The reaction was monitored by TLC. The reaction solution was poured into $0.1 \mathrm{~mol} / \mathrm{L}$ hydrochloric acid, which was then turned basic using an aqueous sodium bicarbonate solution and extracted with ethyl acetate. The organic layer was collected and distilled under reduced pressure. The remaining substance was purified by column chromatography to give purified compound $37(2.5 \mathrm{~g}, 60 \%)$. MS $\mathrm{m} / \mathrm{z}$ (ESI) found $377(\mathrm{M}+\mathrm{H})^{+}$; ${ }^{1} \mathrm{H} \mathrm{NMR}(400 \mathrm{MHz}$, chloroformd) $\delta 8.91(\mathrm{~d}, J=1.0 \mathrm{~Hz}, 1 \mathrm{H}), 8.77(\mathrm{dd}, J=1.8,0.9 \mathrm{~Hz}, 1 \mathrm{H}), 8.53(\mathrm{~d}$, $J=5.8 \mathrm{~Hz}, 1 \mathrm{H}), 8.35(\mathrm{~s}, 1 \mathrm{H}), 7.84(\mathrm{~d}, J=5.8 \mathrm{~Hz}, 1 \mathrm{H}), 7.67(\mathrm{~d}, J=3.7$ $\mathrm{Hz}, 1 \mathrm{H}), 7.63(\mathrm{dd}, J=9.5,0.9 \mathrm{~Hz}, 1 \mathrm{H}), 7.53(\mathrm{dd}, J=9.5,1.8 \mathrm{~Hz}$, $1 \mathrm{H}), 6.80(\mathrm{dd}, J=3.7,0.9 \mathrm{~Hz}, 1 \mathrm{H})$.

3-((1H-pyrrolo[3,2-c]pyridin-1-yl)sulfonyl)-6-phenylimidazo[1,2-a]pyridine (20). A solution of $37(50 \mathrm{mg}$, $0.133 \mathrm{mmol})$, phenylboronic acid $(24.2 \mathrm{mg}, 0.199 \mathrm{mmol})$, $\mathrm{PdCl}_{2}(\mathrm{dppf})-\mathrm{CH}_{2} \mathrm{Cl}_{2}$ adduct $(5.4 \mathrm{mg}, 0.007 \mathrm{mmol})$ and $\mathrm{K}_{2} \mathrm{CO}_{3}$ (55 mg, $0.398 \mathrm{mmol})$ in 1,4-dioxane:water $(4 \mathrm{~mL}, 2: 1, v / v)$ in a microwave tube was flushed with $\mathrm{N}_{2}$ for 5 min then sealed. The tube was placed in a microwave cavity and heated at $90^{\circ} \mathrm{C}$ for $60 \mathrm{~min}$. Then, the reaction mixture was evaporated to dryness. The residue was purified by flash chromatography to give $20(39.7 \mathrm{mg}, 80 \%)$. MS $\mathrm{m} / z$ (ESI) found $375(\mathrm{M}+\mathrm{H})^{+}$; 
${ }^{1} \mathrm{H}$ NMR (400 MHz, chloroform-d) $\delta 8.91$ (s, 1H), 8.71-8.69 $(\mathrm{m}, 1 \mathrm{H}), 8.53(\mathrm{~d}, J=5.8 \mathrm{~Hz}, 1 \mathrm{H}), 8.43(\mathrm{~s}, 1 \mathrm{H}), 7.91(\mathrm{~d}, J=6.2 \mathrm{~Hz}$, $1 \mathrm{H}), 7.79(\mathrm{dd}, J=9.4,0.9 \mathrm{~Hz}, 1 \mathrm{H}), 7.75-7.63(\mathrm{~m}, 2 \mathrm{H}), 7.59-7.37$ $(\mathrm{m}, 5 \mathrm{H}), 6.79(\mathrm{dd}, J=3.7,0.7 \mathrm{~Hz}, 1 \mathrm{H})$. Retention time $2.82 \mathrm{~min}$, $100 \%$ pure.

The details of compounds $\mathbf{2 1 - 3 1}$ are provided in the Supporting Material.

\section{Molecular docking}

The X-ray complex structure of an azaindole compound bound to c-Met (PDB entry: 2WD1 ${ }^{[22]}$ ) was downloaded from the PDB database. The Schrödinger software package was used for the modeling studies. First, the structure was subjected to Protein Preparation Wizard to add the hydrogen atoms and refine the structure to eliminate the improper interactions. Then, the Glide program was used to generate the grid file. The receptor grid was defined as an enclosed box centered at the ligand in the ATP binding site. Docking was performed using the Glide software in standard precision (SP) mode with the default parameters ${ }^{[23]}$. Finally, the binding interactions were analyzed and illustrated with the Pymol program.

\section{ELISA kinase assay}

The effects of the compounds on the activities of various tyrosine kinases were determined using enzyme-linked immunosorbent assays (ELISAs) with purified recombinant proteins. Briefly, $20 \mu \mathrm{g} / \mathrm{mL}$ poly(Glu, Tyr)4:1 (Sigma, St Louis, MO, USA) was pre-coated in 96-well plates as a substrate. A $50-\mu \mathrm{L}$ aliquot of $10 \mu \mathrm{mol} / \mathrm{L}$ ATP solution diluted in kinase reaction buffer (50 mmol/L HEPES [pH 7.4], $50 \mathrm{mmol} / \mathrm{L} \mathrm{MgCl}_{2}, 0.5$ $\mathrm{mmol} / \mathrm{L} \mathrm{MnCl}_{2}, 0.2 \mathrm{mmol} / \mathrm{L} \mathrm{Na}_{3} \mathrm{VO}_{4}$, and $1 \mathrm{mmol} / \mathrm{L} \mathrm{DTT}$ ) was added to each well. Then, $1 \mu \mathrm{L}$ of various concentrations of compounds diluted in 1\% DMSO (v/v) (Sigma, St Louis, $\mathrm{MO}, \mathrm{USA})$ were then added to each reaction well. DMSO (1\%, $v / v$ ) was used as a negative control. The kinase reaction was initiated adding purified tyrosine kinase proteins diluted in $49 \mu \mathrm{L}$ of kinase reaction buffer. After incubation for $60 \mathrm{~min}$ at $37^{\circ} \mathrm{C}$, the plate was washed three times with phosphatebuffered saline (PBS) containing 0.1\% Tween 20 (T-PBS). Antiphosphotyrosine (PY99) antibody $(100 \mu \mathrm{L} ; 1: 500$, diluted in 5 $\mathrm{mg} / \mathrm{mL}$ BSA T-PBS) was then added. After a 30-min incubation at $37^{\circ} \mathrm{C}$, the plate was washed three times, and $100 \mu \mathrm{L}$ of horseradish peroxidase-conjugated goat anti-mouse IgG (1:2000, diluted in $5 \mathrm{mg} / \mathrm{mL}$ BSA T-PBS) was added. The plate was then incubated at $37^{\circ} \mathrm{C}$ for an additional $30 \mathrm{~min}$ and washed 3 times. A $100-\mu \mathrm{L}$ aliquot of a solution containing $0.03 \% \mathrm{H}_{2} \mathrm{O}_{2}$ and $2 \mathrm{mg} / \mathrm{mL}$ o-phenylenediamine in $0.1 \mathrm{~mol} / \mathrm{L}$ citrate buffer ( $\mathrm{pH} 5.5)$ was added. The reaction was terminated by adding $50 \mu \mathrm{L}$ of $2 \mathrm{~mol} / \mathrm{L} \mathrm{H}_{2} \mathrm{SO}_{4}$; as the color changed, the plate was analyzed using a multi-well spectrophotometer (SpectraMAX 190, from Molecular Devices, Palo Alto, CA, USA) at $490 \mathrm{~nm}$. The inhibition rate (\%) was calculated using the following equation: $\left[1-\left(A_{490} / A_{490}\right.\right.$ control $\left.)\right] \times 100$. The $\mathrm{IC}_{50}$ values were calculated from the inhibition curves in two separate experiments.

\section{Cell culture}

EBC-1, MKN-45, and MKN-1 cells were purchased from Japanese Research Resources Bank (Tokyo, Japan). NCIH661, A549, KATOIII and DU145 cells were purchased from the American Type Culture Collection (Manassas, VA, USA). NCI-H358, BGC-823, MGC-803 and NCI-H460 were obtained from the Typical Culture Preservation Commission Cell Bank at the Chinese Academy of Sciences. NCI-H3122 was obtained from the National Cancer Institute. MDCK cells were a kind gift from Dr H Eric XU at the Shanghai Institute of Materia Medica. The cells were routinely maintained according to the recommendations of their suppliers ${ }^{[24]}$.

\section{Cell proliferation assay}

Cells were seeded in 96-well tissue culture plates. On the next day, the cells were exposed to various concentrations of compounds and further cultured for $72 \mathrm{~h}$. Cell proliferation was then determined using sulforhodamine B (SRB, from SigmaAldrich, St Louis, MO, USA) or a Cell Counting Kit (CCK-8) assay. The $\mathrm{IC}_{50}$ values were calculated by fitting concentration-response curves using a SoftMax pro-based four-parameter method.

\section{Western blot analysis}

EBC- 1 cells were treated with the indicated dose of compound 31 for $2 \mathrm{~h}$ at $37^{\circ} \mathrm{C}$ and then lysed in $1 \times$ SDS sample buffer. The cell lysates were subsequently resolved by 10\% SDS-PAGE and transferred to nitrocellulose membranes. The membranes were probed with the appropriate primary antibodies (ie, [c-Met (Santa Cruz, CA, USA), phospho-c-Met, phospho-ERK, ERK, phospho-AKT, AKT (all from Cell Signaling Technology, Beverly, MA, USA), and GAPDH (KangChen Biotech, Shanghai, China)) and then with horseradish peroxidase-conjugated anti-rabbit or anti-mouse $\operatorname{IgG}^{[25]}$. The immunoreactive proteins were detected using an enhanced chemiluminescence detection reagent (Thermo Fisher Scientific, Rockford, IL, USA).

\section{Scattering assay}

MDCK cells $\left(1.5 \times 10^{3}\right.$ cells per well $)$ were plated in $96-$ well plates and grown overnight. Increasing concentrations of Compound 31 and HGF (50 ng/mL) were added to the appropriate wells, and the plates were incubated at $37^{\circ} \mathrm{C}$ and $5 \% \mathrm{CO}_{2}$ for $24 \mathrm{~h}$. The cells were fixed with $4 \%$ paraformaldehyde for $15 \mathrm{~min}$ at room temperature and then stained with $0.2 \%$ crystal violet. The assay was performed in triplicate. Images were obtained using an Olympus IX51 microscope.

\section{Results and Discussion}

To identify the binding mode of compound 5, we utilized the Glide program to perform a docking study on 5 in the ATP binding site of c-Met. The crystal structure of 2WD1 was selected as a template, and the protein structure was first refined for glide grid generation. Then, the minimized compound 5 was docked into the binding site. As shown in Figure $2 \mathrm{~A}$, the binding conformation of 5 indicated that the hinge 
binder was an imidazole group and that the 4-fluoro-benzene group was situated below the side chain of residue Tyr1230 to form a п-п stacking interaction. To verify whether the imidazole unit was the hinge binder, we synthesized 7 compounds by replacing imidazole with different substituted aromatic 5 -member rings. As shown in Table 1, when the $\mathrm{N}$ atom at the 3 -position was removed or changed to the 2-position ( 6 and 7), the activities dramatically decreased, which informed us that it may be advantageous to have an $\mathrm{H}$-bond receptor at the 3-position to interact with the essential hinge part of the binding site. To test our hypothesis, some H-bond receptors such as a nitryl group or an aldehyde group were installed. The results demonstrated that compounds with substitutions at the 3 -position exhibited significantly better activities than those with substitutions at the 2-position (comparing 8 to 9 and $\mathbf{1 0}$ to 11, respectively). However, compound 12, which had an ethanone structure at the 3-position, did not show good inhibitory activity, indicating that the methyl group caused steric hindrance when the compound approached the carbonyl group of the binding site (comparing compounds 10 and 12).

From Table 1, we found H-bond receptors at the 3-position of the imidazole ring improved activities. Therefore, diversi- fied bicycle-aromatic rings containing the $\mathrm{H}$-bond acceptor $\mathrm{N}$ atom were introduced, and the synthesized compounds were tested in enzymatic assays (Table 2). Compounds 13, 14 and $\mathbf{1 5}$ had similar enzyme inhibitory activities against c-Met. When the pyridine ring was replaced by a phenyl ring (16), the compounds lost their activities, reinforcing the finding that pyridine plays an important role in protein-ligand interactions. When a halogen atom was introduced on the carbon adjacent to the $\mathrm{N}$ atom $(\mathbf{1 7}, 18$ and 19), the activities also decreased dramatically, suggesting that the halogen atoms could interfere with nearby residues in the hinge part of the binding site.

The nearly identical activities of $\mathbf{1 3}$ and $\mathbf{1 4}$ puzzled us regarding their binding conformations because the position of the important nitrogen atoms were different in the pyrrolopyridine rings, which were thought to be essential in $\mathrm{H}$-bond interactions. From the interaction pattern found in the crystal structure $2 \mathrm{WD} 1$, compound $\mathbf{1 3}$ would bind to the ATP site by forming a hydrogen bond with the backbone of residue Met1160. However, compound $\mathbf{1 4}$ had a shifted nitrogen atom, which could not fulfill the requirement of interacting with the hinge part of the protein. Thus, we performed a docking study with the aim of predicting the interaction mode

Table 1. The enzymatic inhibition activities of compounds 5-12.

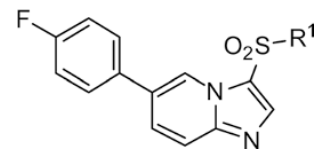

\begin{tabular}{|c|c|c|c|c|c|}
\hline \multirow[t]{2}{*}{ Cpd. } & \multirow[t]{2}{*}{$\mathrm{R}^{1}$} & \multicolumn{3}{|c|}{ Enzyme inhibition } & \multirow[t]{2}{*}{$\mathrm{IC}_{50}(\mathrm{nmol} / \mathrm{L})$} \\
\hline & & $1 \mu \mathrm{mol} / \mathrm{L}$ & $0.1 \mu \mathrm{mol} / \mathrm{L}$ & $0.01 \mu \mathrm{mol} / \mathrm{L}$ & \\
\hline 5 & & 85.9 & 13.5 & / & $181.5 \pm 31.6$ \\
\hline 6 & & 31.7 & 27.5 & 21.1 & / \\
\hline 8 & & 97.8 & 87.7 & 40.8 & / \\
\hline 9 & & 0 & 9.3 & -3.5 & / \\
\hline 11 & & 9.4 & -25.1 & -15.2 & / \\
\hline 12 & & 80.7 & 24.5 & 6.6 & / \\
\hline
\end{tabular}

The inhibition values are estimated values from two separate experiments. The $\mathrm{IC}_{50}$ values were calculated by the Logit method from the results of at least two independent tests with six concentrations each and expressed as mean \pm SD. 

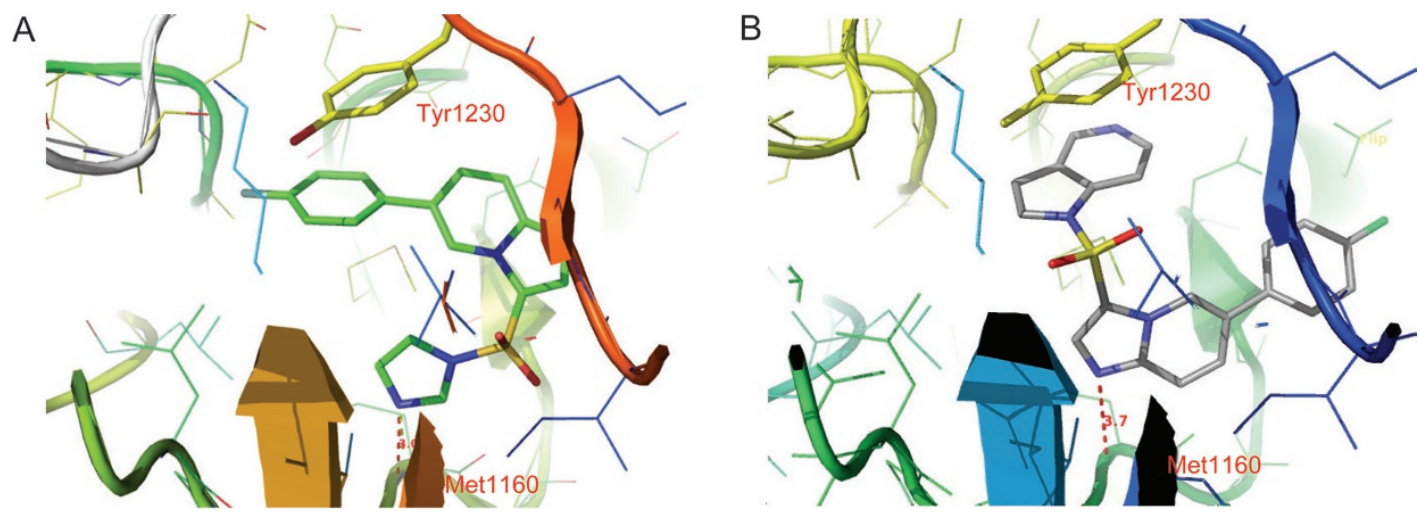

Figure 2. The predicted binding conformation of inhibitors 5 (A) and 14 (B) in the ATP binding site of c-Met based on the docking studies. The ligands were shown in stick model, while the protein were shown in cartoon.

Table 2. The enzymatic inhibition activities of compounds 13-19.<smiles>O=[SH]c1cnc2ccc(-c3ccc(F)cc3)cn12</smiles>

\begin{tabular}{|c|c|c|c|c|c|}
\hline \multirow[t]{2}{*}{ Cpd. } & \multirow[t]{2}{*}{$\mathrm{R}^{1}$} & \multicolumn{3}{|c|}{ Enzyme Inhibition } & \multirow[t]{2}{*}{$\mathrm{IC}_{50}(\mathrm{nmol} / \mathrm{L})$} \\
\hline & & $1 \mu \mathrm{mol} / \mathrm{L}$ & $0.1 \mu \mathrm{mol} / \mathrm{L}$ & $0.01 \mu \mathrm{mol} / \mathrm{L}$ & \\
\hline 13 & & 100 & 92.1 & 48.8 & $15.1 \pm 4.5$ \\
\hline 14 & & 100 & 96.9 & 43.3 & $15.2 \pm 4.2$ \\
\hline 15 & & 97.1 & 89.1 & 44 & $20.2 \pm 0.6$ \\
\hline 16 & & 35.2 & 29.2 & 29.4 & / \\
\hline 17 & & 44.4 & 48.4 & 4.4 & / \\
\hline 18 & & 9.8 & -17.4 & -22.2 & / \\
\hline 19 & & -8.9 & -23.4 & 3 & / \\
\hline
\end{tabular}

The inhibition values are estimated values from two separate experiments. The $\mathrm{IC}_{50}$ 's were calculated by the Logit method from the results of at least two independent tests with six concentrations each and expressed as mean \pm SD.

of compound 14. As shown in Figure 2B, the binding mode of compound 14 was dramatically different from that of compound 13 because the structure was reversed and a hydrogen bond between the imidazo[1,2-a]pyridine ring and residue
Met1160 was observed. This surprising binding conformation triggered us to pursue further optimizations based on this novel scaffold.

As demonstrated by the prediction of the binding conforma- 
tion of compound 14, the 4-fluoro-benzene group coupled to imidazo[1,2-a]pyridine pointed to the solvent-accessible part of the c-Met. Therefore, different heterocycles or substituted phenyl groups were evaluated for their occupancy of the solvent accessible subpocket (Table 3). Most of the compounds showed excellent c-Met inhibition in an enzymatic assay, but many of them did not show good cellular activities in EBC-1 cancer cells. The enzyme $\mathrm{IC}_{50}$ values of compounds $\mathbf{2 4}$ and 29 were $6.6 \pm 1.9$ and $224.1 \pm 74.8 \mathrm{nmol} / \mathrm{L}$, respectively, while their $\mathrm{IC}_{50}$ values in EBC-1 cells were similar (ie, their $\mathrm{IC}_{50}$ values were approximately $500 \mathrm{nmol} / \mathrm{L}$ ). On the whole, $\mathrm{R}^{2}$ with substituted phenyl groups showed better activities than those

Table 3. The enzymatic inhibition activities and cellular activities of compounds 20-31.

\begin{tabular}{|c|c|c|c|c|c|c|}
\hline Cpd. & $R^{2}$ & $\mathrm{IC}_{50}(\mathrm{nmol} / \mathrm{L})$ & $1 \mu \mathrm{mol} / \mathrm{L}$ & $\begin{array}{c}\text { EBC-1 } \\
0.2 \mu \mathrm{mol} / \mathrm{L}\end{array}$ & $0.04 \mu \mathrm{mol} / \mathrm{L}$ & $\mathrm{IC}_{50}(\mathrm{nmol} / \mathrm{L})$ \\
\hline 20 & & $71.3 \pm 18.0$ & 25.4 & -8.5 & -8.9 & / \\
\hline 21 & & $82.3 \pm 28.7$ & 88.3 & 17.8 & 2.5 & $326.6 \pm 94.1$ \\
\hline 22 & & $20.7 \pm 4.0$ & 89.4 & 87.6 & 66.7 & $80.5 \pm 12.3$ \\
\hline 23 & & $40 \pm 1 \mu \mathrm{mol} / \mathrm{L}$ & / & / & / & / \\
\hline 24 & & $224.1 \pm 74.8$ & 88.8 & 8.5 & -9.9 & $543.7 \pm 105.6$ \\
\hline 25 & & $102.0 \pm 30.9$ & 90.7 & 79.0 & 11.5 & $447.0 \pm 121.3$ \\
\hline 26 & & $31.4 \pm 0.1 \mu \mathrm{mol} / \mathrm{L}$ & / & / & / & / \\
\hline 27 & & $78.2 \pm 4.5$ & 27.4 & -11.1 & -12.6 & / \\
\hline 28 & & $74.4 \pm 2.1$ & 29.6 & -13.5 & -10.8 & / \\
\hline 29 & & $6.6 \pm 1.9$ & 81.7 & -3.5 & -11.8 & $539.5 \pm 98.3$ \\
\hline 30 & & $14.8 \pm 0.1 \mu \mathrm{mol} / \mathrm{L}$ & / & / & / & / \\
\hline 31 & & $12.8 \pm 1.5$ & 91.0 & 94.8 & 69.3 & $19.8 \pm 1.6$ \\
\hline
\end{tabular}

The inhibition values are estimated values from two separate experiments. The $\mathrm{IC}_{50}$ values were calculated by the Logit method from the results of at least two independent tests with six concentrations each and expressed as mean \pm SD. 
with heterocycles; in particular, compound 31 exhibited strong inhibition on both molecular and cellular levels.

\section{Compound $\mathbf{3 1}$ is a potent and selective inhibitor of c-Met}

In an enzymatic screen designed to identify c-Met inhibitors, compound $\mathbf{3 1}$ was distinguished for its potency against recombinant human c-Met kinase and exhibited an average $\mathrm{IC}_{50}$ value of $12.8 \mathrm{nmol} / \mathrm{L}$ (Table 3 ). Accordingly, we were prompted to investigate whether this potency was specifically against c-Met. Thus, the activity of Compound $\mathbf{3 1}$ was evaluated against a panel of kinases (Table 4). In contrast to its high potency against c-Met, Compound 31 barely inhibited the kinase activity of other tested tyrosine kinases, including c-Met family member Ron and highly homologous kinases Axl, Tyro3, c-Mer $\left(\mathrm{IC}_{50}>1 \mu \mathrm{mol} / \mathrm{L}\right)$, indicating that compound 31 is a selective c-Met inhibitor.

Table 4. Kinase selectivity profile of compound 31.

\begin{tabular}{ll}
\hline Kinase & $\mathrm{IC}_{50}(\mathrm{nmol} / \mathrm{L})$ \\
\hline c-Met & $12.8 \pm 1.5$ \\
Ron & $>1000$ \\
Axl & $>1000$ \\
Tyro3 & $>1000$ \\
Mer & $>1000$ \\
ALK & $>1000$ \\
PDGFR- $\alpha$ & $>1000$ \\
PDGFR- $\beta$ & $>1000$ \\
EGFR & $>1000$ \\
ErbB2 & $>1000$ \\
ErbB4 & $>1000$ \\
FGFR1 & $>1000$ \\
RET & $>1000$ \\
KDR & $>1000$ \\
FIt-1 & $>1000$ \\
C-SrC & $>1000$ \\
EPH-A2 & $>1000$ \\
\hline
\end{tabular}

The ability of Compound 31 to inhibit the enzymatic activities of a panel of recombinant tyrosine kinases was evaluated by ELISA assays, representing $\mathrm{IC}_{50} \mathrm{~S}$ as mean $\pm \mathrm{SD}$ or estimated values.

Compound 31 inhibits c-Met phosphorylation and its downstream signaling pathways

To further assess the cellular activity of Compound 31 against c-Met kinase, we measured its effects on the phosphorylation of c-Met and downstream signaling molecules in EBC-1 cells that harbor an amplified MET gene. As shown in Figure 3, Compound 31 significantly inhibited the phosphorylation of c-Met with a complete abolishment at $40 \mathrm{nmol} / \mathrm{L}$ in EBC-1 cells, including the phosphorylation of Akt and ERK, which are key downstream molecules of $\mathrm{c}-\mathrm{Met}^{[26]}$. These results suggested that Compound 31 exhibits effective inhibition of c-Met activation and its signaling.

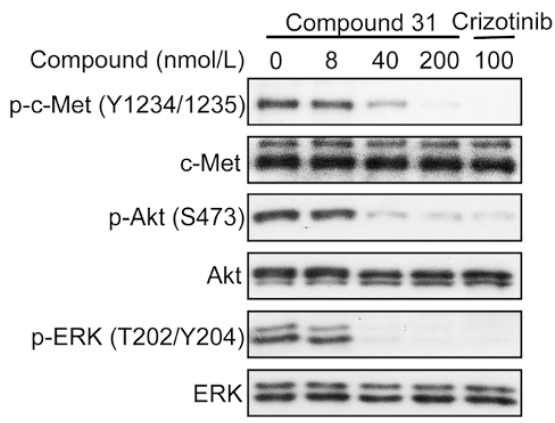

Figure 3. Compound 31 suppresses C-Met phosphorylation and downstream signaling in EBC-1 cells. Cells were treated with indicated concentrations of Compound $\mathbf{3 1}$ for $2 \mathrm{~h}$ and analyzed by immunoblot.

Compound 31 significantly inhibits c-Met-addicted proliferation Activated c-Met is known to trigger cancer cell proliferation ${ }^{[27]}$. Therefore, we next assessed the effect of Compound 31 on cell proliferation in human cancer cells and genetically engineered cells that harbor different backgrounds of c-Met expression and activation. Compound $\mathbf{3 1}$ significantly inhibited the proliferation of the c-Met-constitutively activated EBC-1 and MKN45 cells, with $\mathrm{IC}_{50}$ values of 19.8 and $9.9 \mathrm{nmol} / \mathrm{L}$, respectively (Table 5). In contrast, compound 31 showed over 500fold less potency in cells with low c-Met expression or activation (Table 5). These data indicate that Compound 31 specifically inhibits c-Met-dependent cancer cell growth.

Table 5. Anti-proliferative activity of Compound 31.

\begin{tabular}{lc}
\hline $\mathrm{IC}_{50}(\mathrm{nmol} / \mathrm{L})$ & Compound 31 \\
\hline EBC-1 & $19.8 \pm 1.6$ \\
MKN45 & $9.9 \pm 3.3$ \\
A549 & $>10000$ \\
NCl-H3122 & $>10000$ \\
NCl-H358 & $>10000$ \\
NCI-H661 & $>10000$ \\
NCI-H460 & $>10000$ \\
BGC-823 & $>10000$ \\
KATO III & $>10000$ \\
MGC-803 & $>10000$ \\
MKN-1 & $>10000$ \\
DU145 & $>10000$ \\
\hline
\end{tabular}

The $\mathrm{IC}_{50}$ values are shown as the mean $\pm \mathrm{SD}(\mathrm{nmol} / \mathrm{L})$ or estimated values from two separate experiments.

\section{Compound 31 inhibits c-Met-dependent cell scattering}

Activated HGF/c-Met signaling is also known to promote cell scattering that stimulates cells to abandon their original environment, a hallmark of cancer invasiveness and metastasis $^{[28]}$. It has been well documented that MDCK cells, which normally grow in clusters, are disruptive and scatter cell colo- 
nies upon HGF stimulation. We thus determined the effect of compound $\mathbf{3 1}$ on this cell scattering behavior using MDCK cells stimulated by HGF. As shown in Figure 4, treatment with compound $\mathbf{3 1}$ reduced the HGF-induced cell scattering of MDCK cells in a dose-dependent manner, completely blocking the spreading of cells at a dose of $500 \mathrm{nmol} / \mathrm{L}$.

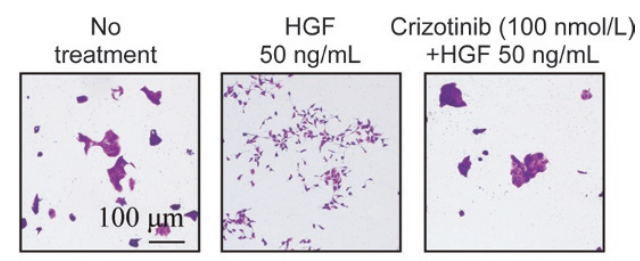

Compound 31 (nmol/L)+HGF $50 \mathrm{ng} / \mathrm{mL}$

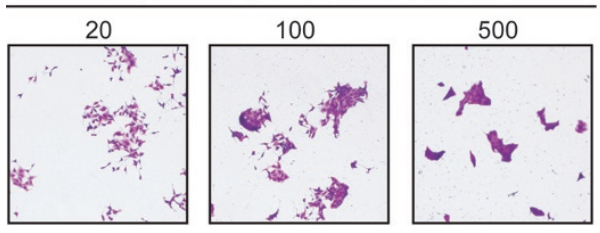

Figure 4. Compound 31 inhibits HGF-induced cell scattering. Cell scattering of MDCK cells induced by HGF were dose-dependently inhibited by Compound 31. Representative images from two separate experiments are shown (scale bar, $100 \mu \mathrm{m}$ ).

\section{Discussion}

Based on the previously identified lead compound 4, we synthesized an interesting compound $\mathbf{5}$ during the development of c-Met inhibitors. According to the docking prediction, we proposed that the imidazole of compound $\mathbf{5}$ would form a hydrogen bonding interaction with the hinge part of the ATP binding site of c-Met. The structure-activity relationships of synthesized compounds $\mathbf{6 - 1 2}$ were consistent with this hypothesis. Further optimization resulted in a novel compound, 14, which contained a pyrrolo[3,2-c]pyridine scaffold. A docking study of this compound suggested that it could interact with c-Met in a reversed conformation by using the imidazo[1,2-a]pyridine as a hinge binder. Following this finding, further optimization resulted in the synthesis of compound 31, the most potent compound, which exhibited potent enzymatic inhibition activity with an $\mathrm{IC}_{50}$ of $12.8 \mathrm{nmol} / \mathrm{L}$. Compound 31 effectively inhibited overactivated c-Met signaling in EBC-1 cancer cells. In turn, compound 31 suppressed c-Met-dependent cell proliferation and cell scattering. This discovery will benefit other researchers and enable the development of a novel series of c-Met inhibitors as anti-cancer drugs.

An interesting feature of Compound 31 was its selectivity against c-Met. Compound 31 presented $\mathrm{IC}_{50}$ values for c-Met in the nanomolar range in a kinase assay and showed more than a 78 -fold selectivity over a panel of 16 human kinases, including c-Met family member Ron and highly homologous kinases, such as Axl, Tyro3 and Mer. Consistently, the anti- proliferative activity of compound $\mathbf{3 1}$ was more than 500 -fold potent for c-Met-addicted cells in contrast to a panel of tumor cell lines with low c-Met expression and activation levels. In fact, most c-Met inhibitors currently undergoing clinical trials are multi-target inhibitors, which may result in unwanted offtarget toxicity ${ }^{[29]}$. Specific c-Met inhibitors could largely avoid toxicity arising from the targeting of extra molecules and thus provide a better option for the sub-population of c-Met-driven cancers in the new era of precision medicine. The high specificity and potency of compound $\mathbf{3 1}$ give it the potential to act as a tool inhibitor in preclinical use and allows it to be a promising novel drug candidate for further development.

\section{Acknowledgements}

We are grateful for financial support from the Foundation of China Postdoctoral Science, the National Natural Science Foundation of China (№ 81202391, 91229205, 81473243, 81321092 and 81330076) and the National Science \& Technology Major Project "Key New Drug Creation and Manufacturing Program" of China (№ 2014ZX09507002, 2012ZX09301001007 and 2013ZX09507001). The SA-SIBS Scholarship Program is also gratefully acknowledged.

\section{Author contribution}

Bing XIONG, Jing AI and Dong-mei ZHAO designed the research; Tong-chao LIU, Xia PENG, Yu-chi MA and Yin-chun JI conducted the research; Dan-qi CHEN, Ming-yue ZHENG, Mao-sheng CHENG, Mei-yu GENG and Jing-kang SHEN analyzed the data; Bing XIONG, Jing AI, and Dong-mei ZHAO wrote the paper.

\section{Supplementary information}

Chemical experimental procedures and analytical data for the mentioned compounds are available in the supplementary Information at the website of Acta Pharmacologica Sinica.

\section{References}

1 Cooper CS, Park M, Blair DG, Tainsky MA, Huebner K, Croce CM, et al. Molecular-cloning of a new transforming gene from a chemically transformed human cell-line. Nature 1984; 311: 29-33.

2 Holmes O, Pillozzi S, Deakin JA, Carafoli F, Kemp L, Butler PJG, et al. Insights into the structure/function of hepatocyte growth factor/ scatter factor from studies with individual domains. J Mol Biol 2007; 367: 395-8.

3 Manning G, Whyte DB, Martinez R, Hunter T, Sudarsanam S. The protein kinase complement of the human genome. Science 2002; 298: 1912-34.

4 Wang MH, Padhye SS, Guin S, Ma Q, Zhou YQ. Potential therapeutics specific to C-MET/RON receptor tyrosine kinases for molecular targeting in cancer therapy. Acta Pharmacol Sin 2010; 31: 1181-8.

5 Bottaro DP, Rubin JS, Faletto DL, Chan AML, Kmiecik TE, Vandewoude $\mathrm{GF}$, et al. Identification of the hepatocyte growth-factor receptor as the c-Met protooncogene product. Science 1991; 251: 802-4.

6 Wang XL, Chen XM, Fang JP, Yang CQ. Lentivirus-mediated RNA silencing of c-Met markedly suppresses peritoneal dissemination of gastric cancer in vitro and in vivo. Acta Pharmacol Sin 2012; 33: 513-22. 
7 Ponzetto C, Bardelli A, Zhen Z, Maina F, Dallazonca P, Giordano $\mathrm{S}$, et al. A multifunctional docking site mediates signaling and transformation by the hepatocyte growth factor scatter factor receptor family. Cell 1994; 77: 261-71.

8 Birchmeier C, Birchmeier W, Gherardi E, Vande WGF. Met, metastasis, motility and more. Nat Rev Mol Cell Biol 2003; 4: 915-25.

9 Trusolino L, Bertotti A, Comoglio PM. MET signalling: principles and functions in development, organ regeneration and cancer. Nat Rev Mol Cell Biol 2010; 11: 834-48.

10 Chmielowiec J, Borowiak M, Morkel M, Stradal T, Munz B, WernerS, et al. c-Met is essential for wound healing in the skin. J Cell Biol 2007; 177: 151-62.

11 Comoglio PM, Trusolino L. Invasive growth: from development to metastasis. J Clin Invest 2002; 109: 857-62.

12 He CX, Ai J, Xing WQ, Chen Y, Zhang HT, Huang M, et al. Yhhu3813 is a novel selective inhibitor of c-Met kinase that inhibits c-Metdependent neoplastic phenotypes of human cancer cells. Acta Pharmacol Sin 2014; 35: 89-97.

13 Qian J, Zhu CH, Tang S, Shen AJ, Ai J, Li J, et al. $\alpha 2,6$-Hyposialylation of c-Met abolishes cell motility of ST6Gal-I-knockdown HCT116 cells. Acta Pharmacol Sin 2009; 30: 1039-45.

14 Yu Z, Ma YC, Ai J, Chen DQ, Zhao DM, Wang X, et al. Energetic factors determining the binding of type I inhibitors to c-Met kinase: experimental studies and quantum mechanical calculations. Acta Pharmacol Sin 2013; 34: 1475-83.

15 Otsuka T, Takayama H, Sharp R, Celli G, LaRochelle WJ, Bottaro DP, et al. c-Met autocrine activation induces development of malignant melanoma and acquisition of the metastatic phenotype. Cancer Res 1998; 58: 5157-67.

16 Umeki K, Shiota G, Kawasaki H. Clinical significance of c-met oncogene alterations in human colorectal cancer. Oncology 1999; 56: 314-21.

17 Cui JJ. Targeting receptor tyrosine kinase MET in cancer: small molecule inhibitors and clinical progress. J Med Chem 2014; 57 : 4427-53.

18 Cui JJ, Tran-Dube M, Shen H, Nambu M, Kung PP, Pairish M, et al. Structure based drug design of crizotinib (PF-02341066), a potent and selective dual inhibitor of mesenchymal-epithelial transition factor (c-MET) kinase and anaplastic lymphoma kinase (ALK). J Med
Chem 2011; 54: 6342-63.

19 Atreya CE, Song EK, Messersmith W, Purkey A, Bagby S, Quackenbush $\mathrm{K}$, et al. Potent antitumor activity of XL184 (cabozantinib), a c-MET and VEGFR2 inhibitor, in colorectal cancer patient-derived tumor explant models. Int J Cancer 2015; 136: 1967-75.

20 Munshi N, Jeay S, Li YZ, Chen CR, France DS, Ashwell MA, et al. ARQ 197, a novel and selective inhibitor of the human c-Met receptor tyrosine kinase with antitumor activity. Mol Cancer Ther 2010; 9: 1544-53.

21 Ma YC, Sun GQ, Chen DQ, Peng X, Chen YL, Su Y, et al. Design and optimization of a series of 1-sulfonylpyrazolo[4,3-b]pyridines as selective c-Met inhibitors. J Med Chem 2015; 58: 2513-29.

22 Porter J, Lumb S, Franklin RJ, Gascon-Simorte JM, Calmiano M, Riche $\mathrm{KL}$, et al. Discovery of 4-azaindoles as novel inhibitors of c-Met kinase. Bioorg Med Chem Lett 2009; 19: 2780-4.

23 Friesner RA, Banks JL, Murphy RB, Halgren TA, Klicic JJ, Mainz DT, et al. Glide: a new approach for rapid, accurate docking and scoring. 1. Method and assessment of docking accuracy. J Med Chem 2004; 47: 1739-49.

24 Patil MA, Lee SA, Macias E, Lam ET, Xu CR, Jones KD, et al. Robe of cyclin D1 as a mediator of c-Met- and beta-Catenin-induced hepatocarcinogenesis. Cancer Res 2009; 69: 253-61.

25 Boccaccio C, Comoglio PM. Opinion-Invasive growth: a MET-driven genetic programme for cancer and stem cells. Nat Rev Cancer 2006; 6: 637-45.

26 Bertotti A, Burbridge MF, Gastaldi S, Galimi F, Torti D, Medico E, et al. Only a subset of Met-activated pathways are required to sustain oncogene addiction. Sci Signal 2009; 2(100): ra80. doi: 10.1126/ scisignal.2000643. Erratum in: Sci Signal. 2009 Dec 22; 2(102):er11.

27 Trusolino L, Bertotti A, Comoglio PM. MET signalling: principles and functions in development, organ regeneration and cancer. Nat Rev Mol Cell Biol 2010; 11: 834-8.

28 Stoker M, Gherardi E, Perryman M, Gray J. Scatter factor is a fibroblast-derived modulator of epithelial cell mobility. Nature 1987; 327: $239-42$.

29 Comoglio PM, Giordano S, Trusolino L. Drug development of MET inhibitors: targeting oncogene addiction and expedience. Nat Rev Drug Discov 2008; 7: 504-16. 